$<$ 症例報告 $>$

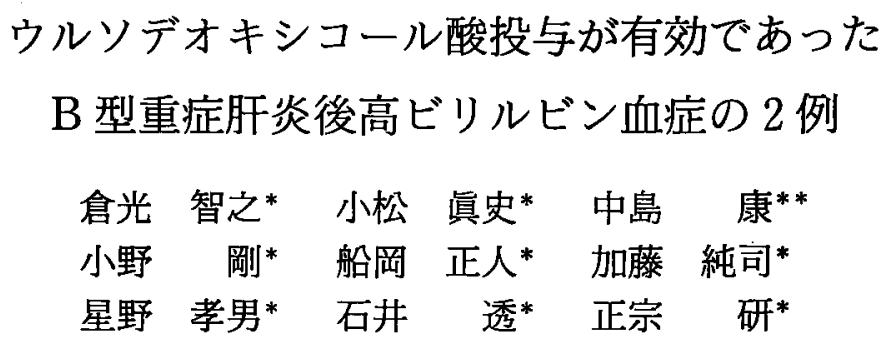

要 旨: 症例 $1 ； 22$ 歳, 女性。B 型急性肝炎発症後18日目に精神症状が出現, 劇症肝炎亜急性 型と診断された。血漿交換，持続緩徐式血液滤過等の治療で急性期にみられた意識障害は改善 したが, $40 \mathrm{mg} / \mathrm{d} l$ 以上の高ビリルビン血症が遷延した. 症例 $2 ； 66$ 歳, 男性. 急性 B 型肝炎に 䍜患し, 劇症肝炎への移行が危惧されたため当科に転院した. 入院後, 新鮮凍結血墏輸血, AT III 製郕等で治療, 精神症状の発現はなかったが, 検査成績は改善せず, $30 \mathrm{mg} / \mathrm{d} l$ 以上の高ビリ ルビン血症が遷延した．両症例の高ビリルビン血症に対しウルソデオキシコール酸 (UDCA) $600 \mathrm{mg} /$ 日を投与し, その後, 血清総ビリルビン值のすみやかな下降と共に, 血清総胆汁酸の減 少, その分画では一次胆汁酸の減少と UDCA の増加が認められた. 重症肝障害後に高ビリルビ ン血症が遷延する場合, UDCA 投与は有効な治療法の一つと考光られた。

索引用語： ウルソデオキシコール酸 劇症肝炎 重症肝炎 高ビリルピン血症

はじめに

Ursodeoxycholic acid（UDCA）は原発性胆汁性肝 硬変など慢性肝内胆汁うっ滞の代表的治療薬である. しかし，劇症肝炎をはじめとする重症肝炎に UDCA を投与することは胆汁うっ滞を助長する可能性があ り，一般に禁忌とされている。一方，近年 A 型劇症肝 炎や薬剤性の劇症肝炎後に高ビリルビン血症が遷延し た場合, UDCA 投与の有用性が指摘されている( 我々は T.Bil $30 \mathrm{mg} / \mathrm{d} l$ 以上の高ビリルビン血症が遷 延した B 型劇症肝炎 1 例, B 型重症肝炎 1 例に UDCA を投与し, 副作用もなく良好な成績を得たの で，血清胆汁酸の推移も含め報告する．

\section{症 例 1}

患者：22歳, 女性.

主訴：意識障害.

家族歴：特記事項なし。

既往歴：2 歳時, 鼠径へルニアで手術. 14歳時, 虫 垂炎で手術.
輸血歴：20歳時, 過多月経あり輸血を受けた。

現病歴：1992年10月, 全身僚急感, 発熱あり近医受 診. $\operatorname{HBsAg}(+)$, AST $545 \mathrm{U} / l$, ALT $1,091 \mathrm{U} / l$ で, B 型急性肝炎と診断され同院に入院した。 その後, フ ロトロンビン時間 $(\mathrm{PT})$ が徐々に延長, 発症より18日 目に不榣状態, 傾眠傾向が出現, 劇症肝炎亜急性型と 診断され秋田大学第一内科に転院した。

入院時現症：意識は傾眠状態で肝性昏睡III度, 全身 に黄疸が著明で皮下出血斑あり：下肢に浮腫を認めた。 腹部に波動があり，肝脾は触知しなかった。

入院時検查成績 (Table 1)：PT は著明に延長, 卜 ランスアミナーゼは中等度に上昇していた，T. Bil は $34.7 \mathrm{mg} / \mathrm{d} l$ と高值で,一方コリンエステラーゼ $(\mathrm{ChE})$ は低下していた．高アンモニア血症があり，アミノ酸 分画でメチオニン (Met) は $165.1 \mathrm{nmol} / \mathrm{m} l$ と高值を示 した. ウイルスマーカーは HBs Ag(+), IgM-HBcAb $(+), \mathrm{HBcAb}$ 低力価陽性, $\mathrm{HBeAg}(+), \mathrm{DNA}$ polymerase $0 \mathrm{cpm}$ であった.

Tomoyuki Kuramitsu*, Masafumi Komatsu*, Ko NaKajima**, Tsuyoshi Ono*, Masato Funaoka*, Junji Kato*, Takao Hoshino*, Tohru IshI" and Osamu MasamunE*

"秋田大学医学部第 1 内科, **仙北組合総合病院内科

<受付日1995年 2 月13日 $>$ 
Table 1 Laboratory data on admission of case 1 .

\begin{tabular}{lc|lc|lc}
\hline RBC & $388 \times 10^{4} / \mu l$ & LDH & $280 \mathrm{U} / l$ & Cre & $0.5 \mathrm{mg} / \mathrm{d} l$ \\
$\mathrm{Hb}$ & $11.2 \mathrm{~g} / \mathrm{d} l$ & $\gamma$-GTP & $25 \mathrm{U} / l$ & FBS & $112 \mathrm{mg} / \mathrm{d} l$ \\
$\mathrm{Ht}$ & $31.9 \%$ & T.Bil & $34.7 \mathrm{mg} / \mathrm{d} l$ & AFP & $2,007.6 \mathrm{ng} / \mathrm{m} l$ \\
WBC & $8,800 / \mu l$ & D.Bil & $20.7 \mathrm{mg} / \mathrm{d} l$ & $\mathrm{NH} 3$ & $188 \mu \mathrm{g} / \mathrm{d} l$ \\
$\mathrm{Plt}$ & $26.0 \times 10^{4} / \mu l$ & TTT & $5.5 \mathrm{MU}$ & Met & $165.1 \mathrm{nmol} / \mathrm{m} l$ \\
$\mathrm{HPT}$ & $14 \%$ & ZTT & $13.0 \mathrm{KU}$ & HBsAg & $(+)$ \\
PT & $15 \%$ & $\mathrm{ChE}$ & $320 \mathrm{U} / l$ & IgM-HBcAb & 7.3 \\
FDP & $4.8 \mu \mathrm{g} / \mathrm{m} l$ & $\mathrm{TP}$ & $5.0 \mathrm{~g} / \mathrm{d} l$ & HBcAb & $(+)$ low titer \\
fibrinogen & $43.0 \mathrm{mg} / \mathrm{d} l$ & $\mathrm{Alb}$ & $2.7 \mathrm{~g} / \mathrm{d} l$ & HBeAg & $(+)$ \\
AT-III & $16.0 \%$ & $\gamma-\mathrm{gl}$ & $1.2 \mathrm{~g} / \mathrm{d} l$ & HBeAb & $(-)$ \\
AST & $90 \mathrm{U} / l$ & $\mathrm{Na}$ & $142 \mathrm{mEq} / l$ & DNA-p & $0 \mathrm{cpm}$ \\
ALT & $110 \mathrm{U} / l$ & $\mathrm{~K}$ & $3.3 \mathrm{mEq} / l$ & IgM-HA & $(-)$ \\
ALP & $133 \mathrm{U} / l$ & $\mathrm{Cl}$ & $98 \mathrm{mEq} / l$ & HCV-Ab & $(-)$ \\
& & $\mathrm{BUN}$ & $7 \mathrm{mg} / \mathrm{d} l$ & HDV-Ab & $(-)$ \\
\hline
\end{tabular}

臨床経過 (Fig. 1)：B 型劇症肝炎垔急性型の診断の もと, 入院時より中心静脈栄養管理とし，4L/日の血獎 交換を 2 日間施行し，更に入院第 3 病日より polyacrylonitrile (PAN) 膜を使用した24時間持続緩徐式 血液滤過を施行した。入院第 8 病日には意識は清明と なったが, PT 21\%，ChE 293U/l と回復せず T. Bil も $33.3 \mathrm{mg} / \mathrm{d} l$ と高值で肝不全状態であった。その後も
T. Bil は徐々に上昇し，入院第 54 病日に $40 \mathrm{mg} / \mathrm{d} l$, 第 56 病日には $47.3 \mathrm{mg} / \mathrm{d} l$ となった. $\mathrm{PT}, \mathrm{ChE}$ も明らかな 改善は認められなかった（PT 25.4\%, ChE 128U/l). 第56病日よりUDCA $600 \mathrm{mg} /$ 日の投与を開始した。 UDCA 投与前の血清総胆汁酸 (TBA) (Fig. 2) は272.0 $\mathrm{nmol} / \mathrm{m} l$, 固定化酵素 HPLC 法で測定した胆汁酸分 画はヶノデオキシコール酸(CDCA) $77.8 \%$ ，コール酸

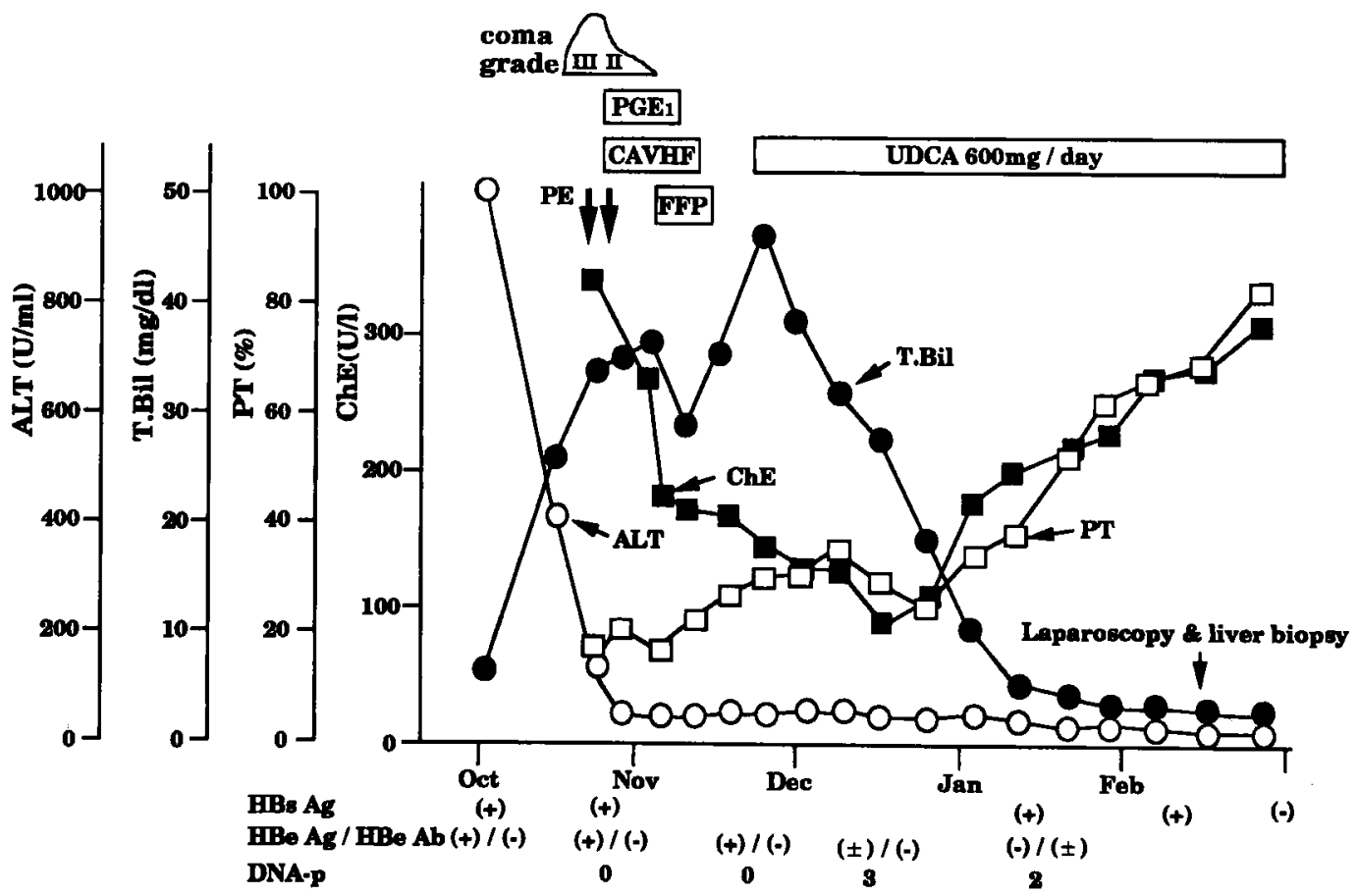

Fig. 1 Clinical course of case 1.

$\mathrm{PE}$ : plasma exchange, $\mathrm{PGE}_{1}$ : prostaglandin $\mathrm{E}_{1}, \mathrm{CAVHF}$ : continuous arteriovenous hemofiltration, FFP: fresh frozen plasma. 

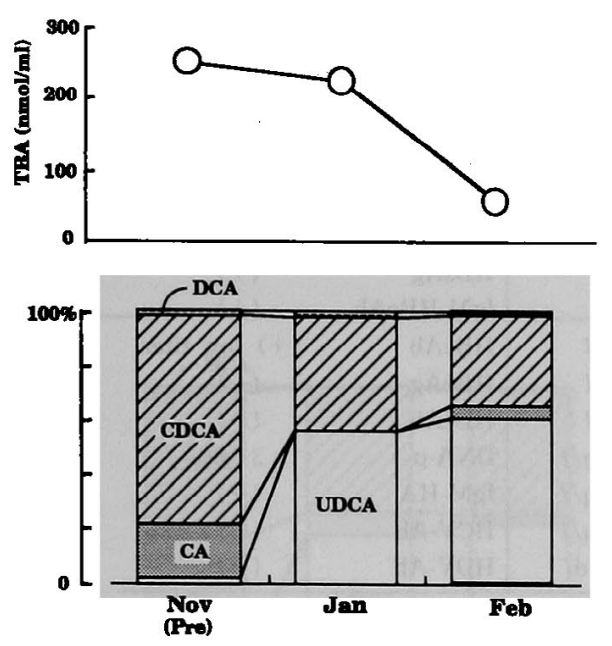

Fig. 2 Total serum bile acids (TBA) concentration and serum bile acid composition during ursodeoxycholic acid treatment of case 1 .

CA : cholic acid, CDCA : chenodeoxycholic acid, DCA : deoxycholic acid, UDCA : ursodeoxycholic acid.

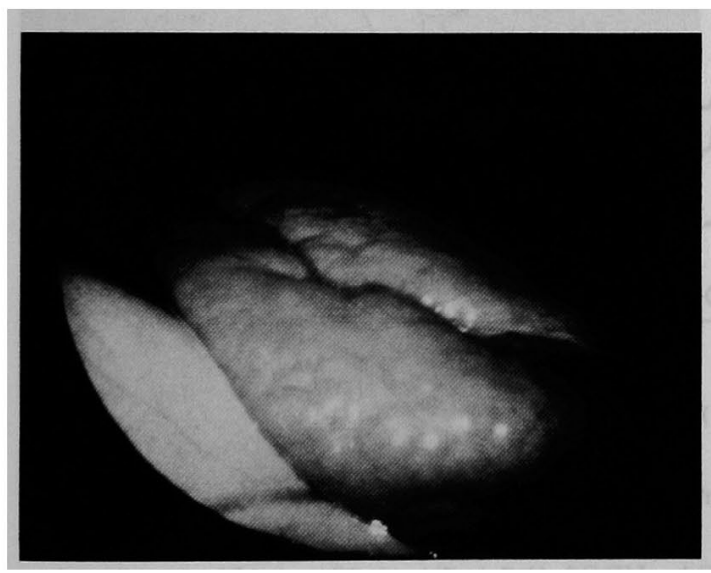

Fig. 3 Laparoscopic appearance of the right lobe of the liver shows diffuse enlargement with a large depressed lesion.

(CA) $20.1 \%$ ，UDCA 1.2\%であり，CA/CDCA 比は 0.26 と著明に低下していた: UDCA 投与 1 力月後, TBA は $246.4 \mathrm{nmol} / \mathrm{m} l$ と軽度隇少, 胆斗酸分画では CDCA，CA はそれそれれ $41.6 \% ， 0.8 \%$ と隇少，逆に UDCA は $55.9 \%$ と增加した. UDCA 投与 2 力月後, $\mathrm{TBA}$ は $85.3 \mathrm{nmol} / \mathrm{m} l$ と著明に減少し, 胆汁酸分画は CDCA, CA, UDCA がそれぞれ32.9\%, 5.2\%, 60.6\% であった。 T. Bil 值は UDCA 投与後より徐々に下降,

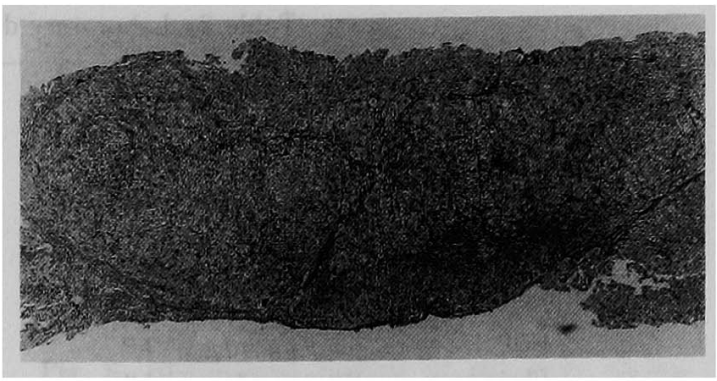

Fig. 4 Histological finding of the liver shows massive necrosis with nodular regeneration intersected by thin fibrous bands.

PT, ChE は UDCA 投与 3 週後より徐々に改善し, 入 院第128病日に退院した。

腹腔鏡検查（入院第121病日）（Fig. 3）：肝は馬鈴薯 肝様の所見を呈した。すなわち，肝右葉は全体的に再 生結節により肥厚し, 深い切れ込みが見られ, 肝左葉 は板状の洀痕肝を呈し, 左葉左緑には深い落込みと大 きな再生結節が認められた。

盰組織像 (Fig. 4)：広範性肝細胞壊死像と共に薄い 隔壁に境された再生塊が認められた。

$$
\text { 症 例 } 2
$$

患者：66歳, 男性.

主訴：全身倦急感。

家族歴：特記事項なし.

既往歴：61歳時，右股関節脱臼で手術を受けた。

輸血歴：なし。

現病歴：1992年12月感冒様症状あり, 近医受診. HBsAg $(+)$, AST $260 \mathrm{U} / l$, ALT $289 \mathrm{U} / l \tau$, B 型 急性肝炎の診断で入院した。 その後, 劇症肝炎への移 行が危惧されたため，秋田大学第一内科に転院した。

入院時現症：意識清明. 全身に黄㾝が著明で皮下出 血斑が認められた．肝濁音界は不明瞭で，肝脾は触知 しなかった。

入院時検查成績（Table 2)：PT は延長, トランス アミナーゼは高值で, T. Bil は $18.8 \mathrm{mg} / \mathrm{d} l$ であった. ChEの低下と高アンモニア血症が認められ, Met は $287.6 \mathrm{nmol} / \mathrm{ml}$ と高値であった。ウイルスマーカーは $\mathrm{HBsAg}(+), \operatorname{IgM}-\mathrm{HBcAb}(+), \mathrm{HBeAg}(+), \mathrm{HBcAb}$ 低力価陽性, DNA-polymerase $3 \mathrm{cpm}$ であった.

臨床経過 (Fig. 5)：B 型急性肝炎の診断の下, 入院 時より中心静脈栄養管理とし, gabexate mesilate, prostaglandin $\mathrm{E}_{1}$, antithrombin III 製剂, アルブミン 製剤, 新鮮凍結血槳輸血等で治療した，肝炎発症後， 
Table 2 Laboratory data on admission of case 2.

\begin{tabular}{lc|lc|lc}
\hline RBC & $514 \times 10^{4} / \mu l$ & LDH & $296 \mathrm{U} / l$ & Cre & $0.7 \mathrm{mg} / \mathrm{d} l$ \\
$\mathrm{Hb}$ & $16.5 \mathrm{~g} / \mathrm{d} l$ & $\gamma$-GTP & $65 \mathrm{U} / l$ & FBS & $80 \mathrm{mg} / \mathrm{d} l$ \\
$\mathrm{Ht}$ & $47.1 \%$ & T.Bil & $18.8 \mathrm{mg} / \mathrm{d} l$ & AFP & $135.5 \mathrm{ng} / \mathrm{m} l$ \\
WBC & $5,600 / \mu l$ & D.Bil & $12.5 \mathrm{mg} / \mathrm{d} l$ & NH3 & $122 \mu \mathrm{g} / \mathrm{d} l$ \\
Plt & $8.2 \times 10^{4} / \mu l$ & TTT & $10.2 \mathrm{MU}$ & Met & $278.6 \mathrm{nmol} / \mathrm{m} l$ \\
HPT & $15.5 \%$ & ZTT & $16.2 \mathrm{KU}$ & HBsAg & $(+)$ \\
PT & $16.3 \%$ & ChE & $170 \mathrm{U} / l$ & IgM-HBcAb & $(+)$ \\
FDP & $5.9 \mu \mathrm{g} / \mathrm{m} l$ & TP & $4.7 \mathrm{~g} / \mathrm{d} l$ & HBcAb & $(+)$ low titer \\
fibrinogen & $113.0 \mathrm{mg} / \mathrm{d} l$ & Alb & $2.1 \mathrm{~g} / \mathrm{d} l$ & HBeAg & $(+)$ \\
AT-III & $18.0 \%$ & $\gamma-\mathrm{gl}$ & $1.3 \mathrm{~g} / \mathrm{d} l$ & HBeAb & $(-)$ \\
AST & $897 \mathrm{U} / l$ & $\mathrm{Na}$ & $136 \mathrm{mEq} / l$ & DNA-p & $3 \mathrm{cpm}$ \\
ALT & $1.338 \mathrm{U} / l$ & $\mathrm{~K}$ & $4.6 \mathrm{mEq} / l$ & IgM-HA & $(-)$ \\
ALP & $145 \mathrm{U} / l$ & $\mathrm{Cl}$ & $104 \mathrm{mEq} / l$ & HCV-Ab & $(-)$ \\
& & $\mathrm{BUN}$ & $12 \mathrm{mg} / \mathrm{d} l$ & HDV-Ab & $(-)$ \\
\hline
\end{tabular}

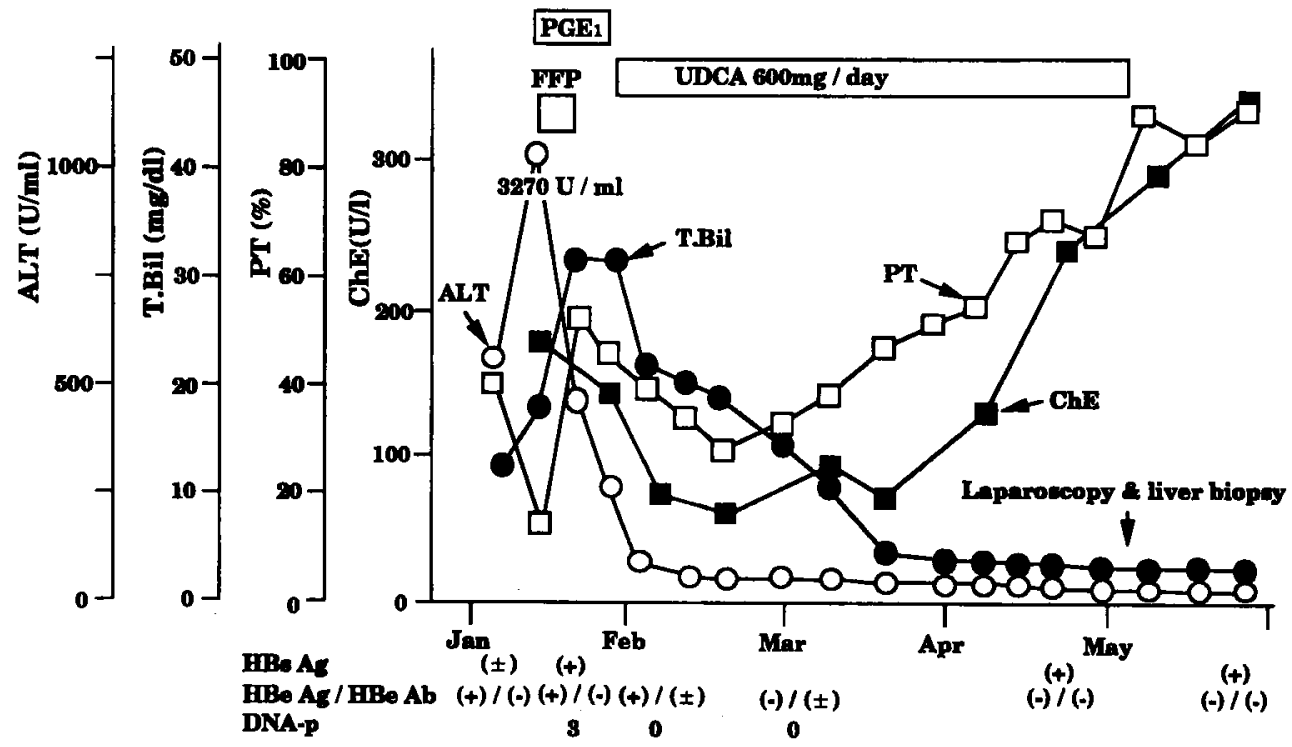

Fig. 5 Clinical course of case 2.

精神症状の発現はなかった．T. Bil は入院第11病日に $32.1 \mathrm{mg} / \mathrm{d} l$ と上昇し, PT $42 \%, \mathrm{ChE} 142 \mathrm{U} / l$ であり, 肝不全の状態であった. その後も T. Bil は $30 \mathrm{mg} / \mathrm{d} l$ 以 上, PT は20〜30\%, $\mathrm{ChE}$ は $100 \mathrm{U} / l$ 以下を推移した. 入院第16病日より UDCA $600 \mathrm{mg}$ /日の経口投与を開始 した. UDCA 投与前 (Fig. 6) の TBA は312.0nmol/ $\mathrm{ml}$, その分画は CDCA $54.0 \%, \mathrm{CA} 43.9 \%$, UDCA $0.5 \%, \mathrm{CA} / \mathrm{CDCA}$ 比0.81であった. UDCA 投与 1 力 月後, TBA は $446.7 \mathrm{nmol} / \mathrm{ml}$ と増加したが, 分画では $\mathrm{CDCA}, \mathrm{CA}$ はそれぞれ $44.6 \% ， 7.7 \%$ と減少，逆に UDCA は $47.6 \%$ と增加した. UDCA 投与 2 力月後, $\mathrm{TBA} は 196.6 \mathrm{nmol} / \mathrm{m} l$ と減少し, 分画では CDCA,
CA，UDCA はそれぞれ43.7\%，4.1\%，52.3\%であっ た. UDCA 投与後 TBA が一時増加した期間も含め, T. Bil 值は増加することなく下降, PT, ChE は UDCA 投与 I カ月後より徐々に改善し,入院第137病日に退院 した。

腹腔鏡検查（入院第115病日）（Fig. 7）：肝は両葉と も広範に平皿状の宿凹が認められ，疲痕肝の所見で あった。

肝組織像 (Fig. 8)：肝細胞壊死像と共に幅の広い隔 壁に境された再生塊が認められた。

$$
\text { 考案 }
$$

劇症肝炎をはじめとする重症肝障害では，肝組織の 


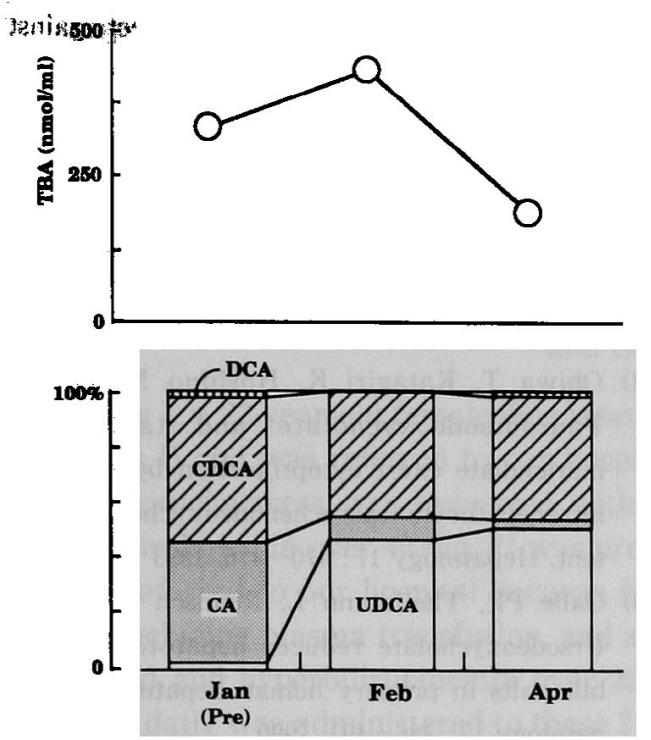

Fig. 6 Total serum bile acids concentration and serum bile acid composition during ursodeoxycholic acid treatment of case 2 .

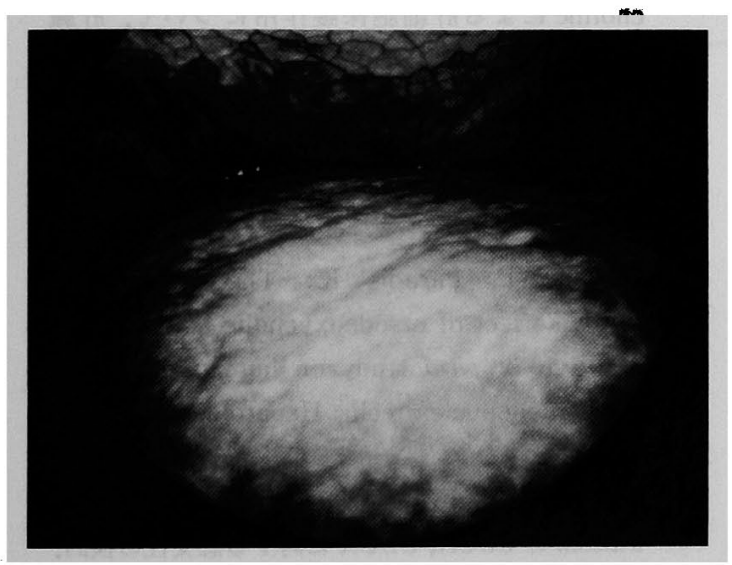

Fig. 7 Laparoscopic appearance of the right lobe of the liver shows diffuse excavated lesion.

広範な壊死が認められ，その治癒には肝細胞の再生が 必須である.また, 重症肝障害では, 急性期を乗り越 えた後も肝臓の機能不全による各種の代謝異常, エン ドトキシン血症が存在して扔り, 十分な肝再生が完了 するまでの間, DIC, 急性膵炎, 肺炎をはじめとする感 染症, 消化管出血, 腎不全等に対する予防および治療 が重要となる.そのため, 肝細胞の再生促進や残存肝 細胞の保護は重症肝障害後の合併症を減らし, 救命率 の上昇につながると考えられる.

UDCA はこれまで, 利胆作用 ${ }^{5)}$, 肝細胞保護作用 ${ }^{6 \sim 9)}$,

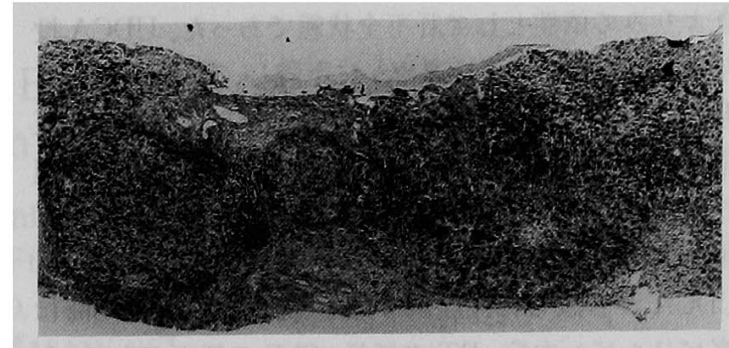

Fig. 8 Histological finding of the liver shows bridging necrosis with nodular regeneration intersected by thick fibrous bands.

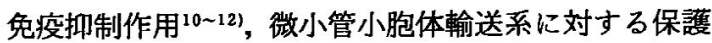
作用 ${ }^{13,14)}$ を有することが報告されている。一方, 肝障害 の急性期での UDCA 投与は，むしろ胆汁うっ帯を助 長し肝細胞障害を増悪させるため禁忌とされている.

しかし, UDCA はその薬理作用として, 細胞障害性 を有する各種胆汁酸のうっ帯による二次的な肝障害を 防止し, 肝再生を促進することから, 重症肝障害でも 急性期を過ぎた時期には，高ビリルビン血症に対する 薬用としてその適応になりうるものと考えられる. 事 実, 最近, 安藤 ${ }^{15)}$ は $\alpha$-naphthyl-isocyanate で胆汁うっ 滞を起こしたラットでは，胆汁うっ滞の急性期，すな わち胆管上皮細胞の変性・壊死期にはUDCA の投与 は減黄効果がなく, 組織学的にも肝障害をむしろ増悪 させるが，急性期を過ぎて胆管上皮細胞障害が回復す る時期ではUDCA の投与によって減黄効果がみら れ，組織学的改善も期待されると報告している.

臨床的にもA 型劇症肝炎や薬剤性劇症肝炎後の高 ビリルビン血症に対し UDCA を投与し，良好な成績 が得られたとの報告が散見される.すなわち, 井上ら は A 型劇症肝炎亜急性型の遷延した黄疸に対し UDCA を使用し著明な減黄効果が得られた 1 例を, 荒 木ら ${ }^{2}$ は A 型劇症肝炎急性型の回復期の黄疸に UDCA が著効した 1 例を, 更に, 河村ら゙も遷延した黄 疸に UDCA が有効であった A 型劇症肝炎の 1 例を報

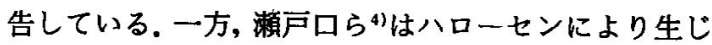
た薬風性の劇症肝炎による黄㾝に対しUDCA を投与 し，有効であったことを報告している.

しかし, B 型劇症肝炎や B 型重症肝炎後の高ビリル ビン血症に対し UDCA を投与し,かつ TBA およびそ の分画の推移についても検討したのは, 我々が医学中 央雑誌で検索した限り見あたらない.

症例 1 は UDCA 投与前, 肝性脳症は改善し, 急性期 は脱していたものの, UDCA 投与開始時血液生化学検 
査よりみて依然として肝不全状態であった. UDCA 投 与後, ビリルビン值は速やかに下降し, PT, ChE も 3 週後には徐々に改善し, 投与 3 力月後にはいずれも正 常に復した。一方, 投与前みられた TBA および一次胆 汁酸 CA, CDCA 濃度の増加も次第に減少すると共に, 胆汁酸分画ではUDCA が大半を占め，逆にCA， CDCA が著減した。症例 2 でも UDCA 投与開始時は 高ビリルビン血症, PT の延長, ChE の低下があり, 入 院時から見られていた肝不全状態が持続していた. UDCA 投与開始後ビリルビン值は速やかに下降し, $\mathrm{PT}, \mathrm{ChE}$ も 1 力月後より徐々に改善し, 投与 3 力月後 には正常に復した.TBA は投与したUDCA の影響で 一時的に增加したが，その後減少し，胆汁酸分画も UDCA の占める割合がほぼ半分を占め,一方, CA の 減少が顕著であった。

我々の 2 症例は肝不全状態においてもUDCA が有 効で高ビリルビン血症の改善の他, UDCA による減黄 効果が肝不全の改善にもつながった可能性を示唆する ものであった. UDCA が高ビリルビン血症を改善する 機序については不明の点が多いが，今後症例を重ねる ことにより重症肝炎に対するUDCA の有用性がより 一層明らかにされるものと考えられた。

\section{結語}

T. Bil $30 \mathrm{mg} / \mathrm{d} l$ 以上の高ビリルビン血症が遷延し た B 型劇症肝炎 1 例, B 型重症肝炎 1 例に対し UDCA を投与し, 良好な成績を得たので, 血清胆汁酸 の推移も含め報告した。

\section{文献}

1）井上純一, 白神邦浩, 荒木康之, 他：A 型劇症肝炎 で黄疸が遷延し ursodeoxycholic acid (UDCA)が 著效を示した 1 例. 忩市病医誌 $6: 1-16,1990$

2）荒木俊江，大森晶彦，小池淳夫，他：A 型劇症肝炎 回復期の黄㾝に UDCA が著効を示した 1 例. 日消 誌 $89: 2369,1992$

3）河村 朗, 岡田昌彦, 石原俊治, 他：遷延した黄疸 にUDCA が有効であった劇症肝炎の 1 例. 日消誌 $90: 1153,1993$

4) 瀬戸口洋一, 尾崎岩太, 本村光明, 他：肝内胆汁う つ滞に対するウルソデオキシコール酸の効果. 新 薬と臨床 $38: 1145-1152,1991$

5) Kitani K, Kanai S: Effect of ursodeoxycholate on the bile flow in the rat. Life Sci 31 : 1973-1985, 1982

6) Heuman DM, Pandak WM, Hylemon PB, et al :
Conjugates of ursodeoxycholate protect against cytotoxicity of more hydrophobic bile salts : In vitro studies in rat hepatocytes and human erythrocytes. Hepatology 14: 920-926, 1991

7) Gülduituna $S$, Zimmer $G$, Imhof $M$, et al : Molecular aspects of membrane stabilization by ursodeoxycholate. Gastroenterology 104 : $1736-1744,1993$

8) Ohiwa $T$, Katagiri $K$, Hoshino $M$, et al : Tauroursodeoxycholate and tauro-betamuricholate exert cytoprotection by reducing intrahepatocyte taurochenodeoxycholate content. Hepatology $17: 470-476,1993$

9) Galle PR, Theilmann L, Readsch R, et al: Ursodeoxycholate reduces hepatotoxicity of bile salts in primary human hepatocytes. Hepatology $12: 486-491,1990$

10）向坂彰太郎, 案納弘子, 神代龍吉, 他：ケノデオキ シコール酸とウルソデオキシコール酸の培養肝細 胞に対する影響とPolyenphosphosphatidyl cholineによる肝細胞保護作用について，肝藏 $25: 350-358,1984$

11) Yoshikawa M, Tsujii $T$, Matsumura $K$, et al : Immunomodulatory effects of ursodeoxycholic acid on immune response. Hepatology $16: 358-$ 364, 1992

12) Lacaille F, Paradis $K$ : The immunosuppresive effect of ursodeoxycholic acid; a comparative in vitro study on human peripheral blood mononuclear cells. Hepatology 18 : 165172,1993

13）倉光智之, 小松真史, 中島 康, 他：微小管おょび kinesin の CDCA, UDCA に対する感受性の検討. 肝臟 $35: 310,1994$

14) Marks DL, LaRusso NF, McNiven MA : Selective inhibition by bile acids of the microtubule-vesicle motor, kinesin, purified from rat liver: A possible mechanism for impaired vesicular transport in cholestasis. Hepatology 16:125A, 1992

15）安藤正也： $\alpha$-naphthyl-isocyanate (ANIT)によ る肝内胆汁うっ滞モデルに対するウルソデオキシ コール酸 (UDCA) の効果，日消誌 89：25862593,1992 


\title{
Two cases of severe hepatitis B with the prolonged icterus improved by administration of ursodeoxycholic acid
}

\author{
Tomoyuki Kuramitsu*, Masafumi Komatsu*, Ko NaKajima**, \\ Tsuyoshi OnO, Masato FunAOKA, Junji KaTO, \\ Takao Hoshino, Tohru IsHII \\ and Osamu MASAMUNE*
}

Case 1; a 22-year-old female developed psychological distress 18 days after the onset of acute hepatitis B and was referred to our hospital under a diagnosis of fulminant hepatitis (subacute type). Consciousness was improved with various treatments including plasma exchange, but hyperbilirubinemia over $40 \mathrm{mg} / \mathrm{d} l$ was prolonged. Case 2; a 66-year-old male with acute hepatitis B was referred to our hospital because fulminant hepatitis was suspected. Inspite of the treatments including plasma transfusion, and administration of ATIII drug, laboratory data were not improved and hyperbilirubinemia over $30 \mathrm{mg} / \mathrm{d} l$ was prolonged. $600 \mathrm{mg}$ ursodeoxycholic acid (UDCA) daily was administered to these 2 cases. Parallel to the decrease of serum total bile acids and the replacement of primary bile acids by UDCA, hyperbilirubinemia was rapidly improved.

\footnotetext{
- The First Department of Internal Medicine, Akita University School of Medicine (Akita)
}

** Senboku Kumiai General Hospital (Akita) 